\title{
New role of quinolones in respiratory tract infections
}

\author{
Ronald F Grossman MD FRCPC FACP FCCP
}

\begin{abstract}
RF Grossman. New role of quinolones in respiratory tract infections. Can J Infect Dis 1998;9(Suppl E):35E-40E.
Because of limited activity of the standard quinolones such as ciprofloxacin and ofloxacin against some clinically important organisms including Streptococcus pneumoniae and methicillin-resistant Staphylococcus aureus, new quinolones have been developed. In addition to their improved activity against $S$ pneumoniae, some also demonstrate excellent anaerobic activity. None of the quinolones have a role to play in the treatment of paediatric infections. Quinolones (both older and newer agents) have demonstrated equivalent efficacy to standard antimicrobials in the treatment of acute sinusitis. Several groups have suggested that quinolones are excellent agents in the treatment of high risk patients with acute exacerbations of chronic bronchitis. These patients include the elderly, and those with frequent exacerbations, significant comorbid conditions, long duration of chronic bronchitis and major impairment of lung function. There is no evidence to suggest that the newer quinolones will differ from the currently available agents for this disease. The major advantage of the newer quinolones appears to be in the treatment of patients with community-acquired pneumonia where pneumococcal infection is a real concern. A new parenteral quinolone with pneumococcal activity may replace the standard macrolide/cephalosporin combination that is commonly prescribed. For patients with nosocomial pneumonia, the newer agents are alternative choices, especially among patients with early onset pneumonia (less than five days of hospitalization), but are unlikely to replace ciprofloxacin in the intensive care unit setting because of poor Pseudomonas aeruginosa coverage.
\end{abstract}

Key Words: Anaerobic activity, Nosocomial pneumonia, Quinolones

\section{Le nouveau rôle des quinolones dans les infections respiratoires}

RÉSUMÉ : Compte tenu de l'activité limitée des quinolones classiques, comme la ciprofloxacine et l'ofloxacine, contre certains organismes pathogènes cliniquement importants, dont Streptococcus pneumonia et les souches de Staphylococcus aureus méthicillino-résistantes, de nouvelles quinolones ont été mises au point. En plus d'une activité accrue contre $S$. pneumoniax, certaines manifestent également une excellente activité contre les anaérobies. Aucune des quinolones ne joue un rôle dans le traitement des infections pédiatriques. Les quinolones, tant anciennes que nouvelles, ont fait preuve d'une efficacité équivalente à celle des antimicrobiens ordinaires dans le traitement de la sinusite aiguë. Selon plusieurs groupes, les quinolones sont d'excellents agents chez les patients à haut risque souffrant d'exacerbation aiguë de bronchite chronique. Ces patients sont les gens âgés, ceux dont les exacerbations sont fréquentes, ceux qui présentent des comorbidités significatives, ceux dont la bronchite chronique dure depuis longtemps et qui souffrent d'une atteinte importante de leur fonction pulmonaire. Rien ne suggère que les quinolones plus récentes ne différeraient des agents actuellement employés contre cette maladie. Le principal avantage des nouvelles quinolones serait qu'elles conviennent aux patients atteints de pneumonie extra-hospitalière, lorsque l'infection pneumococcique est réellement inquiétante. Une nouvelle quinolone parentérale dotée d'une activité anti-pneumococcique pourrait remplacer les associations macrolides/céphalosporines standard couramment prescrites. Pour les patients qui souffrent de pneumonie nosocomiale, de nouveaux agents offrent des solutions de rechange, surtout pour les patients chez qui la pneumonie dure depuis peu (moins de cinq jours d'hospitalisation), mais ne seront pas appelés à remplacer la ciprofloxacine à l'unité des soins intensifs à cause de sa piètre efficacité contre Pseudomonas aeruginosa.

$\mathrm{Q}$ uinolones are an important class of antimicrobial agents used to treat a variety of bacterial infections. Their supeior pharmacokinetic and pharmacodynamic properties, bactericidal activity, excellent clinical responses and few side effects explain their widespread acceptance in clinical prac- tice. These agents typically have bactericidal activity against most species of bacteria, with minimal bactericidal concentrations equal to or twofold higher than the minimal inhibitory concentrations (1). The absolute bioavailability exceeds $50 \%$, and long terminal half-lives allow once or twice daily dosing 
TABLE 1

Microbial causes of community-acquired acute bacterial sinusitis

\begin{tabular}{lcc}
\hline Organism & $\begin{array}{c}\text { Mean percentage } \\
\text { Adults }\end{array}$ & $\begin{array}{c}\text { Children } \\
\text { Che) of cases }\end{array}$ \\
\hline Streptococcus pneumoniae & $34(23-54)$ & $41(36-47)$ \\
Haemophilus influenzae & $35(19-60)$ & $29(27-32)$ \\
Anaerobes & $6(0-10)$ & 0 \\
Staphylococcus aureus & $4(0-8)$ & 0 \\
Streptococcus pyogenes & $2(1-3)$ & $2(2)$ \\
Moraxella catarrhalis & $2(0-8)$ & $26(23-27)$ \\
Gram-negative bacteria & $4(0-11)$ & $2(2)$ \\
\hline
\end{tabular}

(2). The currently used quinolones, such as ciprofloxacin or ofloxacin, exhibit limited activity against some clinically important organisms, such as Streptococcus pneumoniae and methicillin-resistant Staphylococcus aureus (3). The unique advantage of the new fluoroquinolones as a class is their improved antipneumococcal activity, even in penicillin-resistant strains, while some also demonstrate excellent anaerobic activity. With the emerging global trend of $S$ pneumoniae exhibiting reduced susceptibility to penicillin and, in the case of Gram-negative bacilli, the emergence of multiresistant strains of Enterobacteriaceae, increasing use of fluoroquinolones is predictable. This review examines the current role of fluoroquinolones and speculates on how the newer agents may change the current paradigm.

\section{UPPER AIRWAY INFECTIONS}

Quinolones do not play a role in the treatment of pharyngitis or simple otitis media. Because the new fluoroquinolones have safety profiles similar to the older quinolones, it is unlikely that they will be used in the treatment of these mainly paediatric disorders. Fluoroquinolones have been used in the treatment of acute and chronic sinusitis, chronic otitis media and malignant external otitis. Haemophilus influenzae, $S$ pneumoniae and Moraxella catarrhalis are the principle pathogens in acute sinusitis $(4,5)$ (Table 1). The role of antibiotics in the treatment of acute maxillary sinusitis has been questioned. In a recent placebo-controlled trial, antibiotic treatment did not improve the clinical course of patients with acute maxillary sinusitis presenting to physicians in a primary care setting (6). Others have demonstrated that patients suffering from the common cold, who also have respiratory pathogens ( $H$ influenzae, $M$ catarrhalis, $S$ pneumoniae) isolated from nasopharyngeal secretions, benefit clinically from the administration of antibiotics (7). Until recently, the available fluoroquinolones were not indicated for the treatment of acute purulent sinusitis because of their perceived inactivity against $S$ pneumoniae (8). While not generally considered to be the drugs of first choice, older quinolones have comparable efficacy to cephalosporins and beta-lactams in randomized clinical trials (9). In the treatment of chronic bacterial sinusitis, ciprofloxacin has been reported to be as effective as amoxicillin/clavulanic acid, with clinical resolution and/or improvement reported in more than $80 \%$ of patients in both groups (10). The newer fluoroquinolones have been studied in patients with acute bacterial sinusitis because of the drugs' improved activity against all respiratory pathogens. In a double-blind, multicentre trial, 382 patients with acute purulent sinusitis were treated with either sparfloxacin or cefuroxime axetil (11). The success rates were $82.6 \%$ and $83.2 \%$, respectively; the success rates in the subset of patients with $S$ pneumoniae as the offending pathogen were equivalent (89.5\% for sparfloxacin versus $92.3 \%$ for cefuroxime axetil). Clinical trials with grepafloxacin and trovafloxacin are in progress, but similar success rates can be expected.

Pseudomonas aeruginosa, $S$ aureus and Proteus mirabilis are the main pathogens identified in patients with chronic otitis media, a disease characterized by mucopurulent otorrhoea (12). Patients receiving ciprofloxacin for this indication had a significantly higher clinical response and bacteriological cure rate than patients receiving amoxycillin/clavulanic acid (13). It is difficult to imagine that the new quinolones will improve on this performance because their activity against $P$ aeruginosa is less than that observed with ciprofloxacin. Malignant external otitis, a disease caused by $P$ aeruginosa, occurs in elderly diabetic patients and can lead to osteomyelitis of the base of the skull (14). Treatment of this syndrome with ciprofloxacin has been associated with excellent clinical and bacteriological responses and shorter hospital stays, although controlled clinical trials have not been performed $(15,16)$. Given these observations, it seems prudent to continue to recommend ciprofloxacin as the best agent for these disorders.

\section{LOWER RESPIRATORY TRACT INFECTIONS}

Acute exacerbations of chronic bronchitis: Chronic obstructive pulmonary disease (COPD) is the fourth leading cause of death in the United States and continues to afflict $20 \%$ of the population despite public education about the risks of smoking $(17,18)$. The mortality rate from this disease has increased, while mortality rates from coronary artery disease, stroke and all other causes of death have declined (19). Acute bronchitis and acute exacerbations of chronic bronchitis (AECB) are common illnesses encountered by general and family physicians, and account for approximately 14 million physician visits per year in the United States $(20,21)$. In Europe, more than $80 \%$ of all lower respiratory tract infections are treated with antibiotics (22). Most physicians do not differentiate acute bronchitis, AECB, community-acquired pneumonia (CAP) and viral respiratory tract infections. The pattern of antibiotic prescribing for these infections varies from country to country, but there is no clear rationale for antimicrobial choices (23). For example, penicillins are used most frequently in the United Kingdom, tetracyclines in Germany, but third-generation oral cephalosporins predominate in Italy. All countries use quinolones in roughly the same proportion.

An acute exacerbation of COPD is usually defined as an episodic respiratory decompensation without an objectively documented cause, such as pneumonia. It is characterized clinically by increased cough and sputum production, purulence, and dyspnea. Many of these patients are treated with antibiotics, but the efficacy of this treatment has been questioned (24). Patients with at least two of these symptoms have 
TABLE 2

Bacterial pathogens isolated from sputum in patients with acute exacerbations of chronic bronchitis

\begin{tabular}{lcccc}
\hline Study (reference) & Number of isolates & Haemophilus influenzae & $\begin{array}{c}\text { Percentage of total isolates } \\
\text { Moraxella catarrhalis }\end{array}$ & Streptococcus pneumoniae \\
\hline Basran et al (31) & 60 & 43.3 & 3.3 & 25 \\
Chodosh (32) & 214 & 37.9 & 22.4 & 22.4 \\
Aldons (33) & 53 & 70 & 13 & 15 \\
Bachand (34) & 84 & 30 & 10.7 & 21.4 \\
Lindsay et al (35) & 398 & 49.7 & 19 & 17 \\
Neu and Chick (36) & 84 & 46.4 & 28.6 & 25.0 \\
\hline
\end{tabular}

a better outcome and improve more quickly if treated with an antibiotic than with placebo (25). A large study conducted in Italy confirmed the beneficial role of antibiotics, and a recent meta-analysis indicated a small but statistically significant overall benefit in antibiotic-treated patients $(26,27)$. Bacterial pathogens are cultured from lower respiratory secretions in approximately $50 \%$ of patients (28). Other pathogens, such as viruses and bacterial pathogens (for example, chlamydia or mycoplasma), are responsible for a further $20 \%$ to $30 \%$ $(29,30)$. In bacteriologically defined exacerbations, $H$ influen$z a e$ is the most commonly isolated organism (31-36) (Table 2). More recent data indicate that $M$ catarrhalis is the second most common pathogen while $S$ pneumoniae is next in frequency (37). New evidence suggests that Haemophilus parainfluenzae, an organism usually assumed not to be a pathogen, may also be significant (38).

Beta-lactamase-mediated amoxicillin resistance is seen in $20 \%$ to $40 \%$ of $H$ influenzae strains in North America and Europe, and in almost $100 \%$ of $M$ catarrhalis strains (39-41). In a American survey conducted between 1992 and 1993, 30\% of all $H$ influenzae isolates were beta-lactamase producing, and only a few beta-lactamase negative ampicillin-resistant strains were isolated (42). Beta-lactamase production was found in $92 \%$ of 700 strains of $M$ catarrhalis. For $S$ pneumoniae, $15 \%$ of 800 isolates demonstrated intermediate susceptibility to penicillin, while $7 \%$ were penicillin resistant $\left(\mathrm{MIC}_{90}<2.0 \mu \mathrm{g} / \mathrm{mL}\right.$ ).

In a more recent survey conducted between 1994 and 1995, the percentage of $H$ influenzae strains producing betalactamase increased to $36.4 \%$ (43). Another $2.5 \%$ of $H$ influenzae isolates were beta-lactamase negative, but ampicillinresistant. Beta-lactamase producing $M$ catarrhalis increased to $95.3 \%$ of all isolated strains, while the overall frequency of penicillin-resistant S pneumoniae increased to $23.6 \%(44,45)$. Overall, $14.1 \%$ of $S$ pneumoniae isolates demonstrated intermediate resistance, while $9.5 \%$ demonstrated high level resistance. of particular concern was the observation that $9.1 \%$ of strains demonstrated multiple drug resistance.

In managing COPD, it may be advantageous to define a target population at risk based upon severity of disease, as has been done for patients with pneumonia (46). An aggressive approach to the treatment of exacerbations of COPD in this target population may lead to improved outcomes. Risk factors defined in clinical studies that predict either clinical failure, hospitalization, respiratory failure or death include advanced age, significant impairment of lung function, poor performance status, other comorbid conditions (especially chronic heart disease), frequent exacerbations and the requirement for oral corticosteroid medication (47-51). Several groups have recommended that, in patients at risk (ie, the elderly, patients with severe underlying lung disease, patients with frequent exacerbations, patients with comorbid illnesses such as cardiac disease), aggressive antimicrobial therapy directed at resistant organisms be selected (52-54). Quinolones have been used extensively in this group of patients, and clinical results have been excellent $(31,55-59)$. These drugs have been compared with beta-lactams, beta-lactam/beta-lactamase inhibitors, second- and third-generation cephalosporins with few differences being demonstrated. However, most studies have been performed for registration purposes and are designed to show equivalence.

To demonstrate the potential advantages of using quinolones in this group of patients, high risk patients with at least two new respiratory symptoms (increased cough, increased sputum volume, and purulence and dyspnea) should be included (60). In a recently completed study, patients with at least three treated exacerbations in the previous year were randomly assigned to receive either ciprofloxacin or any nonquinolone-based antimicrobial therapy for their next acute exacerbation of chronic bronchitis (61). In this prospective, health economic study, clinical end-points (days of illness, hospitalizations, time to next exacerbation) were blended with quality of life measurements (Nottingham Health Profile, St George's Hospital Respiratory Questionnaire, Health Utility Index) and total respiratory costs from a societal perspective. While the overall results indicated no preference for either treatment arm, the use of ciprofloxacin led to improved clinical outcome, higher quality of life and less costs in patients with risk factors (severe underlying lung disease, more than four exacerbations per year, duration of bronchitis greater than 10 years, elderly, significant comorbid illness). The results of this study suggest that aggressive antimicrobial therapy directed toward resistant organisms in high risk patients is a more effective strategy than no therapy or therapy with older antimicrobials, which would not be effective against beta-lactamase producing $H$ influenzae or $M$ catarrhalis.

There is considerable interest in examining the role of the newer quinolones because these have an excellent spectrum against the pathogens usually found in acute exacerbations of 
chronic bronchitis. In a randomized, multicentre, open label trial, levofloxacin $500 \mathrm{mg}$ once daily for five days was compared with cefuroxime axetil $250 \mathrm{mg}$ twice daily for 10 days (62). Clinical improvement (greater than 90\%) and microbiological eradication rates (greater than 90\%) were similar in both groups. In a randomized, prospective, double-blind trial, grepafloxacin in two doses, $400 \mathrm{mg}$ once daily or $600 \mathrm{mg}$ once daily for 10 days, was compared with ciprofloxacin $500 \mathrm{mg}$ bid for 10 days. The findings indicated that a 10-day course of either dose of grepafloxacin was as effective, clinically and bacteriologically, as ciprofloxacin (63). Preliminary data suggest that the new fluoroquinolones will be as effective as the older quinolones in patients with $\mathrm{AECB}$. Whether there will be any additional advantage over the older agents quinolones is yet to be determined.

CAP: Pneumonia is the sixth most common cause of death in the United States and accounts for approximately 10 million physician visits, 500,000 hospitalizations and 45,000 deaths in the United States (64-65). The most recent Canadian, American and British published guidelines do not recommend quinolones for the treatment of CAP mainly because of the concern about adequate coverage of $S$ pneumoniae $(46,66,67)$. Only the Infectious Diseases Society of America guidelines for the management of CAP recommend the new 'respiratory' quinolones as an alternative single agent in the treatment of these patients (68).

Older quinolones used as monotherapy for CAP have good clinical results. In a study of hospitalized patients with CAP, ofloxacin was as effective as a standard regimen consisting of a beta-lactam with or without a macrolide (69). In a recent randomized, double-blind, parallel group study of patients with mild to moderate CAP, patients receiving sparfloxacin had similar outcomes as those receiving either amoxycillin/clavulanic acid or erythromycin (70). In another study of patients with mild to moderate CAP, levofloxacin had a higher clinical success rate and microbiological eradication rate compared with ceftriaxone and/or cefuroxime axetil (71). In patients with life-threatening CAP, one suggested regimen includes a quinolone in combination with an aminoglycoside and macrolide as initial empirical therapy until the results of microbiological investigations are available (46). Oral fluoroquinolones have also been recommended as acceptable alternatives to macrolides for Legionnaires' disease and probably for Mycoplasma pneumoniae and Chlamydia pneumoniae infections (72).

In an open label study, grepafloxacin $600 \mathrm{mg}$ once daily was highly effective in the management of patients with CAP, including patients with $S$ pneumoniae, $H$ influenzae, $M$ pneumoniae and Legionella pneumophila as the causative pathogens (73). Registration studies have indicated that the eradication of pneumococci from sputum in patients with CAP is greater than $90 \%$ and comparable with amoxycillin, cefaclor and clarithromycin (73). In these same studies, the eradication rate for $H$ influenzae was greater than $90 \%$ and better than amoxycillin, cefaclor and clarithromycin.

The current American Thoracic Society and Canadian Consensus Conference Group guidelines for the management of out-patients with CAP suggest a macrolide or tetracycline as first-line therapy, particularly in young patients without significant comorbidity $(46,66)$. Given the spectrum of the new fluoroquinolones, their ability to penetrate extremely well into lung tissue and the limited supportive clinical data, these compounds should be considered as possible alternatives in the management of these patients. Both documents also recommend either a cephalosporin as a single agent or the combination of a macrolide and cephalosporin for hospitalized patients. Quinolones that can be administered parenterally (levofloxacin, trovafloxacin) may be alternative choices to combination therapy. More data are required to define the role in this setting adequately, but cost considerations will likely be very important in the final decision to use these agents.

Nosocomial pneumonia: Gram-negative organisms and $S$ aureus are the most commonly isolated pathogens in patients with nosocomial pneumonia (75-77). In the recently published American Thoracic Society statement on the treatment of hospital-acquired pneumonia (78), patients were stratified according to the time of onset, presence of specific risk factors and severity of pneumonia. Among patients with early onset pneumonia (less than five days hospitalization), the likely pathogens are enteric Gramnegative rods, $H$ influenzae, methicillin-sensitive $S$ aureus and $S$ pneumoniae. A fluoroquinolone is recommended only for patients allergic to penicillin. Among patients with severe hospital-acquired pneumonia, $P$ aeruginosa or $\mathrm{ACi}$ netobacter species become a serious consideration. Because of the emergence of multiply resistant aerobic Gramnegative bacilli, a fluoroquinolone is recommended in combination with a beta-lactam agent, especially a thirdgeneration antipseudomonal cephalosporin, a betalactam/beta-lactamase inhibitor or an antipseudomonal penicillin. In the absence of $P$ aeruginosa, monotherapy with a quinolone has been demonstrated to be as effective as treatment with third-generation cephalosporins or imipenem $(79,80)$. Monotherapy with high dose ciprofloxacin was compared with monotherapy with high dose imipenem/cilastatin in patients with severe pneumonia. Ciprofloxacin was associated with a better clinical response and an enhanced eradication rate of Enterobacter species. If $P$ aeruginosa was present, neither regimen performed particularly well and resistance developed frequently during therapy. It is possible to step down to oral fluoroquinolone therapy once an adequate clinical response has been demonstrated to initial intravenous therapy (81).

The new fluoroquinolones are active against the usual pathogens causing nosocomial pneumonia. With the exception of trovafloxacin, they demonstrate relatively poor activity against $P$ aeruginosa. Because of the importance of this pathogen, particularly in an intensive care unit setting, ciprofloxacin will likely remain an important agent. These newer agents will be alternative choices for the management of early onset nosocomial pneumonia among patients without specific risk factors. Agents with anaerobic coverage (trovafloxacin, moxifloxacin) may be considered in patients suspected of having anaerobic lung infection (post-thoracoabdominal surgery, witnessed aspiration). 


\section{SUMMARY}

Fluoroquinolones are important broad spectrum antimicrobials used in a wide variety of upper and lower respiratory tract infections. With the introduction of the new 'respiratory' quinolones with improved antipneumococcal activity, their role will undoubtedly expand into the treatment of CAP and nosocomial pneumonia. Whether they will provide additional benefits to our present armamentarium remains to be proven.

\section{REFERENCES}

1. Hooper DC, Wolfson JS. Fluoroquinolone antimicrobial agents. N Engl J Med 1991;324:384-94.

2. Wolfson JS, Hooper DC. Comparative pharmacokinetics of ofloxacin and ciprofloxacin. Am J Med 1989;87(Suppl 6C):31S-6S.

3. Peterson LR, Quick JN, Jensen B, et al. Emergence of ciprofloxacin resistance in nosocomial methicillin-resistant Staphyloccoccus aureus isolates. Resistance during ciprofloxacin plus rifampin therapy for methicillin-resistant $S$ aureus colonization. Arch Intern Med 1990; $150: 2151-5$

4. Hamory BH, Sande MA, Sydnor A Jr, Seale DL, Gwaltney JM Jr. Etiology and antimicrobial therapy of acute maxillary sinusitis. J Infect Dis 1979;139:197-202.

5. Low DE, Desrosiers M, McSherry J, et al. A practical guide for the diagnosis and treatment of acute sinusitis. Can Med Assoc ] 1997;156(Suppl 6):S1-S14

6. van Buchem FL, Knottnerus JA, Schrijnemaekers VJJ, Peeters MF, Primary-care-based randomised placebo-controlled trial of antibiotic treatment in acute maxillary sinusitis. Lancet 1997;349:683-7.

7. Kaiser L, Lew D, Hirschel B, et al. Effects of antibiotic treatment in the subset of common-cold patients who have bacteria in nasopharyngeal secretions. Lancet 1996:347:1507-10.

8. Körner RJ, Reeves DS, MacGowan AP. Dangers of oral fluoroquinolone treatment in community acquired upper respiratory tract infections. BMJ 1994:308:191-2.

9. Klein GL, Heyd A, Echols R. Oral ciprofloxacin vs cefuroxime axetil in acute bacterial sinusitis. Drugs 1993;45(Suppl 3):324.

10. Legent F, Bordure P, Beauvillain C, Berche P. A double-blind comparison of ciprofloxacin and amoxycillin/clavulanic acid in the treatment of chronic sinusitis. Chemotherapy 1994;40(Suppl 1):8-15.

11. Gehanno P, Berche P, and the Sinusitis Study Group. Sparfloxacin versus cefuroxime axetil in the treatment of acute purulent sinusitis. J Antimicrob Chemother 1996:37(Suppl A): 105-14.

12. Brook I, Finegold SM. Bacteriology of chronic otitis media. JAMA $1979 ; 241: 487-8$.

13. Legent F, Bordure P, Beauvillain C, Berche P. Controlled prospective study of oral ciprofloxacin versus amoxycillin/clavulanic acid in chronic suppurative otitis media in adults. Chemotherapy 1994;40(Suppl 1):16-23

14. Rubin J, Yu VL. Malignant external otitis: insights into pathogenesis, clinical manifestations, diagnosis, and therapy. Am J Med 1988;85:391-8.

15. Gehanno P. Ciprofloxacin in the treatment of malignant external otitis. Chemotherapy 1994;40(Suppl 1):35-40.

16. Sade J, Lang R, Goshen S, Kitzes-Cohen R. Ciprofloxacin treatment of malignant external otitis. Am J Med 1989;87(Suppl 5A):138S-41S

17. United States Bureau of the Census. Statistical Abstract of the United States: 1994, 114th edn. Washington, DC: US Bureau of the Census, 1994:95.

18. Woolcock AJ. Epidemiology of chronic airways disease. Chest 1989;96(Suppl 3):302S-6S

19. Higgens MW, Thorn T. Incidence, prevalence and mortality: Intraand intercountry differences. In: Hensley MJ,

Saunder NA, eds. Clinical Epidemiology of Chronic Obstructive Pulmonary Disease. New York: Marcel Dekker, 1990:23-43.

20. Garibaldi RA. Epidemiology of community-acquired respiratory tract infections in adults. Incidence, etiology, and impact. Am J Med 1985; 78(Suppl 6B):32-7.

21. Verheij TJM, Kaptein AA, Mulder JD. Acute bronchitis: aetiology, symptoms and treatment. Fam Pract 1989;6:66-9.

22. Huchon GJ, Gialdroni-Grassi G, Leophonte P, Manresa F, Schaberg T, Woodhead M. Initial antibiotic therapy for lower respiratory tract infection in the community: a European survey. Eur Respir J 1996;9:1590-5

23. Dorca J, Torres A. Lower respiratory tract infections in the community: towards a more rational approach. Eur Respir 1996:9:1588-9.

24. Tager I, Speizer FE. Role of infection in chronic bronchitis. N Engl I Med 1975;292:563-71

25. Anthonisen NR, Manfreda J, Warren CPW, Hershfield ES, Harding GK,
Nelson NA. Antibiotic therapy in exacerbations of chronic obstructive pulmonary disease. Ann Intern Med 1987;106:196-204

26. Allegra L, Grassi C, Grossi E, Pozzi E. Ruolo degli antibiotici nel trattamento delle riacutizza della bronchite cronica. Ital J Chest Dis 1991;45:138-48.

27. Saint S, Bent S, Vittinghoff E, Grady D. Antibiotics in chronic obstructive pulmonary disease exacerbations. A meta-analysis. JAMA 1995;273:957-60.

28. Monso $\mathrm{E}$, Ruiz J, Rosell A, et al. Bacterial infection in chronic obstructive pulmonary disease. A study of stable and exacerbated outpatients using the protected specimen brush. Am J Respir Crit Care Med 1995;152:1316-20.

29. Gump DW, Phillips CA, Forsyth BR, McInosh K, Lamborn KR, Stouch WH. Role of infection in chronic bronchitis. Am Rev Respir Dis 1976;113:465-74.

30. Beaty CD, Grayston TJ, Wang SP, Kuo CC, Reto CS, Martin TR. Chlamydia pneumoniae, strain TWAR, infection in patients with chronic obstructive pulmonary disease. Am Rev Respir Dis 1991;144:1408-10.

31. Basran GS, Joseph J, Abbas AMA, Hughes C, Tillotson GS. Treatment of acute exacerbations of chronic obstructive airways disease - a comparison of amoxycillin and ciprofloxacin. J Antimicrob Chemother 1990;26(Suppl F):19-24.

32. Chodosh S. Bronchitis and asthma. In: Gorbach SL, Bartlett JG, Blacklow NR, eds. Infectious Diseases. Philadelphia: WB Saunders Co, 1992:476-85.

33. Aldons PM. A comparison of clarithromycin with ampicillin in the treatment of outpatients with acute bacterial exacerbation of chronic bronchitis. J Antimicrob Chemother 1991;27(Suppl A):101-8.

34. Bachand RT Jr. Comparative study of clarithromycin and ampicillin in the treatment of patients with acute bacterial exacerbations of chronic bronchitis. J Antimicrob Chemother 1991;27(Suppl A):91-100

35. Lindsay G, Scorer HIN, Carnegie CMD. Safety and efficacy of temafloxacin versus ciprofloxacin in lower respiratory tract infections: a randomized, double-blind trial. J Antimicrob Chemother 1992;30:89-100.

36. Neu HC, Chick TW. Efficacy and safety of clarithromycin compared to cefixime as outpatient treatment of lower respiratory tract infections. Chest 1993;104:1393-9.

37. Leeper K, Jones AM, Tillotson G. The changing etiology of chronic obstructive pulmonary disease (COPD). Chest $1997 ; 112$ (Suppl):21S

38. Hill SL, Pye A, Johnson MM, et al. A role for Haemophilus parainfluenzae in chronic lung disease. Am I Respir Crit Care Med 1997;155(Suppl):A105.

39. Kayser FH, Morenzoni G, Santanam P. The second European collaborative study on the frequency of antimicrobial resistance in Haemophilus influenzae. Eur J Clin Microbial Infect Dis 1990;9:810-7.

40. Jorgensen JH. Update on mechanisms and prevalence of antimicrobial resistance in Hemophilus influenzae. Clin Infect Dis 1992:14:1119-23

41. Doern GV. Trends in antimicrobial susceptibility of bacterial pathogens of the respiratory tract. Am J Med 1995:99(Suppl 6B):3S-7S

42. Barry AL, Pfaller MA, Fuchs PC, Packer RR. In vitro activities of 12 orally administered antimicrobial agents against four species of bacterial respiratory pathogens from US Medical Centers in 1992 and 1993. Antimicrob Agents Chemother 1994:38:2419-25.

43. Doern GV, Brueggemann AB, Pierce G, Holley HP Jr, Raunch A. Antibiotic resistance among clinical isolates of Hemophilus influenzae in the United States in 1994 and 1995 and detection of beta-lactamase-positive strains resistant to amoxicillin-clavulanate: results of a national multicenter surveillance study. Antimicrob Agents Chemother 1997:41:292-7.

44. Doern GV, Brueggemann AB, Pierce G, Hogan T, Holley HP Jr, Rauch A. Prevalance of antimicrobial resistance among 723 outpatients clinical isolates of Moraxella catarrhalis in the United States in 1994 and 1995: results of a 30-center national surveillance study. Antimicrob Agents Chemother 1996;40:2884-6.

45. Doern GV, Brueggemann AB, Holley HP Jr, Rauch AM. Antimicrobial resistance of Streptococcus pneumoniae recovered from outpatients in the United States during the winter months of 1994 to 1995: results of a 30-center national surveillance study. Antimicrob Agents Chemother 1996:40:1208-13.

46. American Thoracic Society. Guidelines for initial management of adults with community-acquired pneumonia: diagnosis, assessment of severity and initial antimicrobial therapy. Am Rev Respir Dis 1993:148:1418-26.

47. Derenne JP, Fleury B, Pariente R. Acute respiratory failure of chronic obstructive pulmonary disease. Am Rev Respir Dis 1988;138:1006-33.

48. Seneff MG, Wagner DP, Wagner RP, Zimmermann JE, Knaus WA. Hospital and 1-year survival of patients admitted to intensive care 
units with acute exacerbation of chronic obstructive pulmonary disease. JAMA 1995:274:1852-7.

49. Anthonisen NR, Wright EC, Hodgkin JE. Prognosis in chronic obstructive pulmonary disease. Am Rev Respir Dis 1986;133:14-20.

50. Ström K. Survival of patients with chronic obstructive pulmonary disease receiving long-term domiciliary oxygen therapy. Am Rev Respir Dis 1993;147:585-91.

51. Ball P, Harris IM, Lowson D, Tillotson G, Wilson R. Acute infective exacerbations of chronic bronchitis. O J Med 1995:88:61-8.

52. Balter MS, Hyland RH, Low DE, et al. Recommendations on the management of chronic bronchitis. Can Med Assoc J 1994:151 (Suppl 10):7-23.

53. Wilson R. Outcome predictors in bronchitis. Chest 1995;108(Suppl 2): 53S-7S.

54. Lode H. Respiratory tract infections: when is antibiotic therapy indicated? Clinical Therapeutics 1991;13:149-56.

55. Grossman RF, Beaupre A, LaForge J, et al. A prospective, randomised parallel single-blind comparison of oral ciprofloxacin with oral cotrimoxazole in the treatment of respiratory tract infections in patients with chronic obstructive lung disease. Drug Invest 1994;8:110-7.

56. Chodosh S. Temafloxacin compared with ciprofloxacin in mild to moderate lower respiratory tract infections in ambulatory patients. A multicenter, double-blind, randomized study. Chest 1991; 100:1497-502.

57. Lindsay G, Scorer HIN, Carnegie CMD. Safety and efficacy of temafloxacin versus ciprofloxacin in lower respiratory tract infections: a randomized, double-blind trial. J Antimicrob Chemother 1992;30:89-100.

58. Chodosh S. Efficacy of fleroxacin versus amoxicillin in acute exacerbations of chronic bronchitis. Am J Med 1993;94(Suppl 3A):131S-5S.

59. Dark DS, Farber M, Rice K, et al. Oral ofloxacin versus cefaclor for LRTIs in adults. Infect Med 1995;12:551-6.

60. Wilson R, Tillotson G, Ball P. Clinical studies in chronic bronchitis: a need for better definition and classification of severity. J Antimicrob Chemother 1996;37:205-8.

61. Grossman RF, Mukerjee J, Vaughan D, et al. A one-year community based health economic study of ciprofloxacin vs. usual antibiotic treatment in acute exacerbations of chronic bronchitis. Chest 1998:113:131-41.

62. DeAbate CA, Russell M, McElvaine P, et al. Safety and efficacy of oral levofloxacin versus cefuroxime axetil in acute bacterial exacerbations of chronic bronchitis. Respir Care 1997;42:206-13.

63. Chodosh S, Lakshminaryan S, Swarz H, Breisch S. Efficacy and safety of a 10-day course of 400 or 600 milligrams of grepafloxacin once daily for treatment of acute bacterial exacerbations of chronic bronchitis: comparison with a 10-day course of 500 milligrams of ciprofloxacin twice daily. Antimicrob Agents Chemother 1998;42:114-20.

64. Centers for Disease Control and Prevention. Premature deaths, monthly mortality and monthly physician contacts - United States. Morb Mort Wkly Rep 1997;46:556.

65. Marston BJ, Plouffe JF, File TM, et al. Incidence of community-acquired pneumonia requiring hospitalizations. Results of a population-based active surveillance study in Ohio. Arch Intern Med 1997;157:1709-18.

66. Mandell LA, Niederman MS, The Canadian Community Acquired
Consensus Group. Antimicrobial treatment of community acquired pneumonia in adults: A conference report. Can J Infect Dis $1993 ; 4: 25-8$

67. The British Thoracic Society. Guidelines for the management of community-acquired pneumonia in adults admitted to hospital. Brit J Hosp Med 1993;49:346-50.

68. Bartlett JG, Breiman RF, Mandell LA, File TM Jr. Communityacquired pneumonia in adults: guidelines for management. The Infectious Diseases Society of America. Clin Infect Dis 1998;26:811-38

69. Plouffe JF, Herbert MT, File TM Jr, et al. ofloxacin versus standard therapy in treatment of community-acquired pneumonia requiring hospitalization. Pneumonia Study Group. Antimicrob Agents Chemother 1996;40:1175-9.

70. Lode H, Garau J, Grassi C, et al. Treatment of community- acquired pneumonia: a randomized comparison of sparfloxacin, amoxycillin-clavulanic acid and erythromycin. Eur Respir ] 1995;8:1999-2007.

71. File TM Jr, Segreti J, Dunbar L, et al. A multicenter, randomized study comparing the efficacy and safety of intravenous and/or oral levofloxacin versus ceftriaxone and/or cefuroxime axetil in treatment of adults with community-acquired pneumonia. Antimicrob Agents Chemother 1997;41:1965-72.

72. Bartlett JG, Mundy LM. Community-acquired pneumonia. N Engl J Med 1995;333:1618-24.

73. Topkis S, Swarz H, Breisch SA, Maroli AN. Efficacy and safety of grepafloxacin $600 \mathrm{mg}$ daily for 10 days in patients with community-acquired pneumonia. Clin Ther 1997;19:975-88.

74. Norrby SR. Grepafloxacin in respiratory tract infections: are we ready to accept a quinolone for empirical treatment? J Antimicrob Chemother 1997;40:(Suppl A):99-101.

75. Rouby JJ, Martin De Lassale E, Poete P, et al. Nosocomial pneumonia in the critically ill. Histologic and bacteriologic aspects. Am Rev Respir Dis 1992;146;1059-66.

76. Horan TC, White JW, Jarvis WR, et al. Nosocomial infection surveillance, 1984. MMWR CDC Surveill Summ 1986;35;17SS-29SS.

77. Craven DE, Steger KA, Barber TW. Preventing nosocomial pneumonia: state of the art and perspectives for the $1990 \mathrm{~s}$. Am J Med 1991;91(Suppl 3B):44S-53S.

78. American Thoracic Society. Hospital-acquired pneumonia in adults: diagnosis, assessment of severity, initial antimicrobial therapy, and preventative strategies. Am J Respir Crit Care Med 1995; 153:1711-25.

79. Peloquin CA, Cumbo TJ. Nix DE, Sands MF, Schentag IJ. Evaluation of intravenous ciprofloxacin in patients with nosocomial lower respiratory tract infections. Impact of plasma concentrations, organism, minimum inhibitory concentration, and clinical condition on bacterial eradication. Arch Intern Med 1989;149:2269-73.

80. Fink MP, Snydman DR, Niederman MS, et al. Treatment of severe pneumonia in hospitalized patients: results of a multicenter, randomized, double-blind trial comparing intravenous ciprofloxacin with imipenem-cilastatin. The Severe Pneumonia Study Group. Antimicrob Agents Chemother 1994:38:547-57

81. Gentry LO, Rodriguez-Gomez G, Kohler RB, Khan FA, Rytel MW. Parenteral followed by oral ofloxacin for nosocomial pneumonia and community-acquired pneumonia requiring hospitalization. Am Rev Respir Dis 1992;145:31-5. 


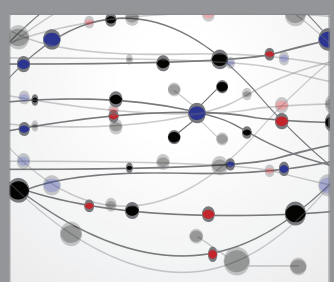

The Scientific World Journal
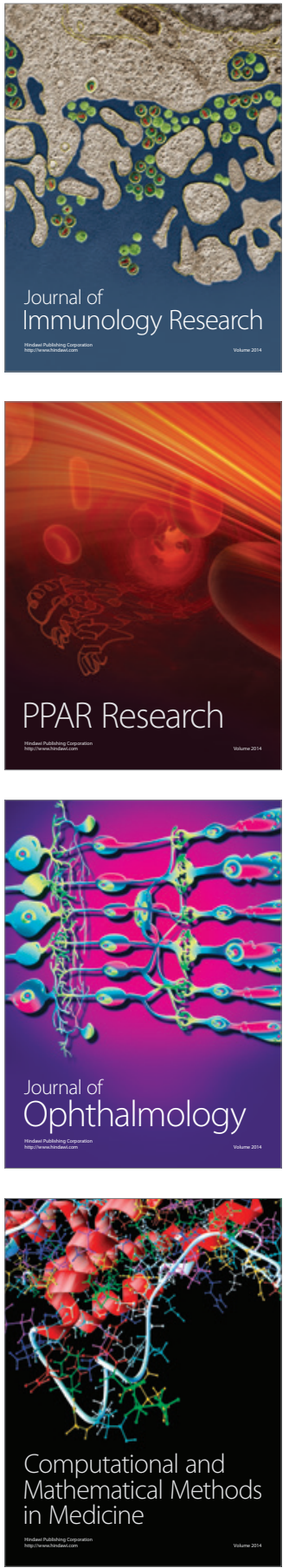

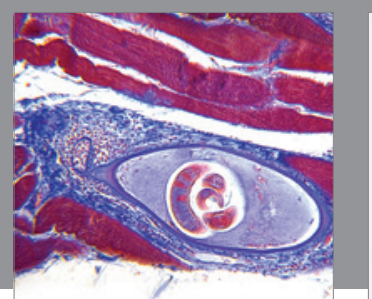

Gastroenterology Research and Practice

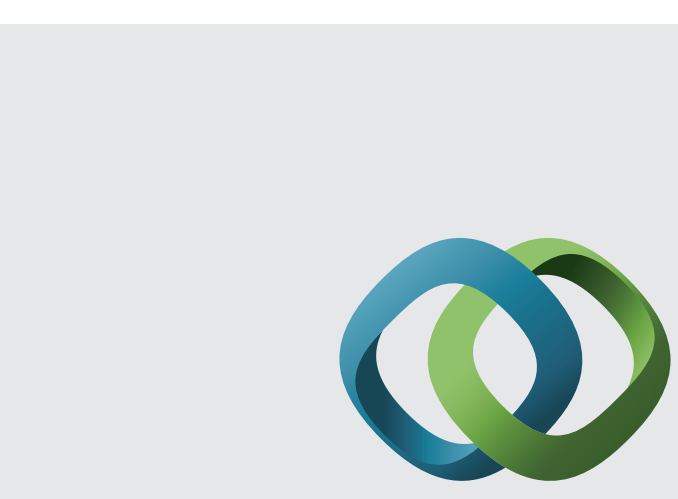

\section{Hindawi}

Submit your manuscripts at

http://www.hindawi.com
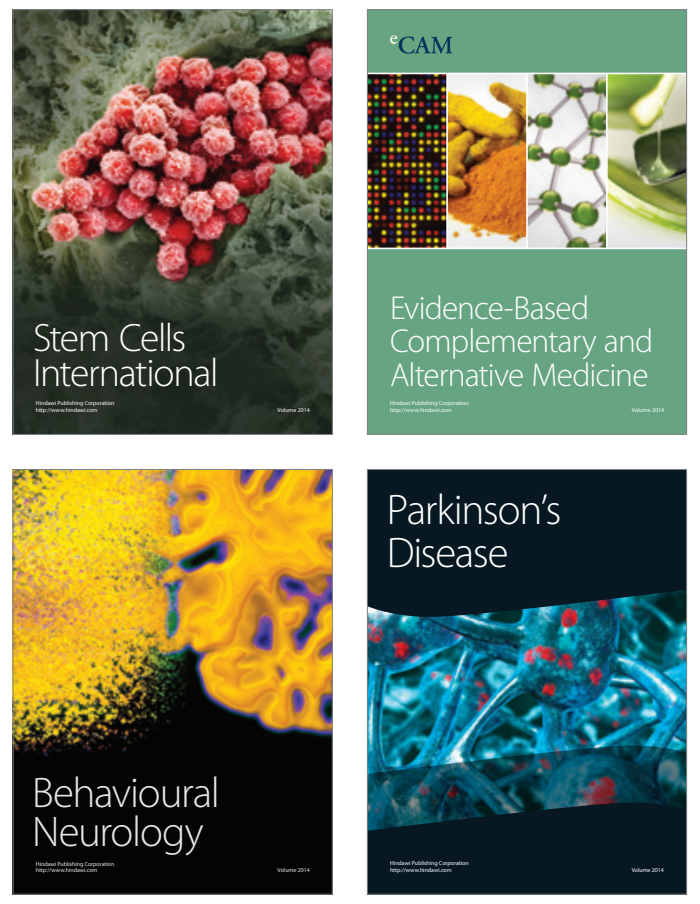
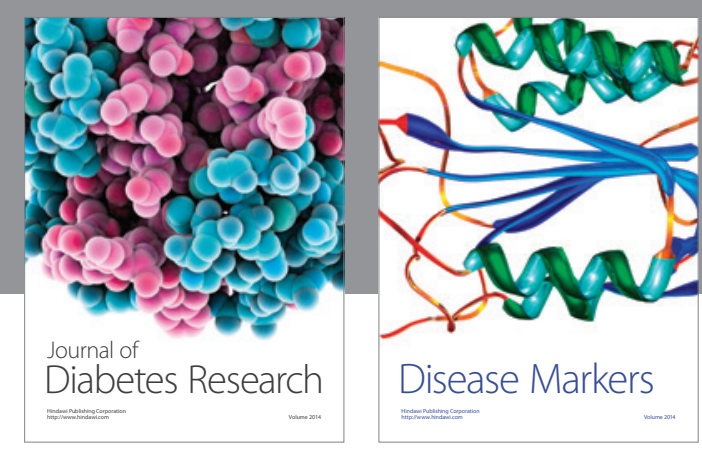

Disease Markers
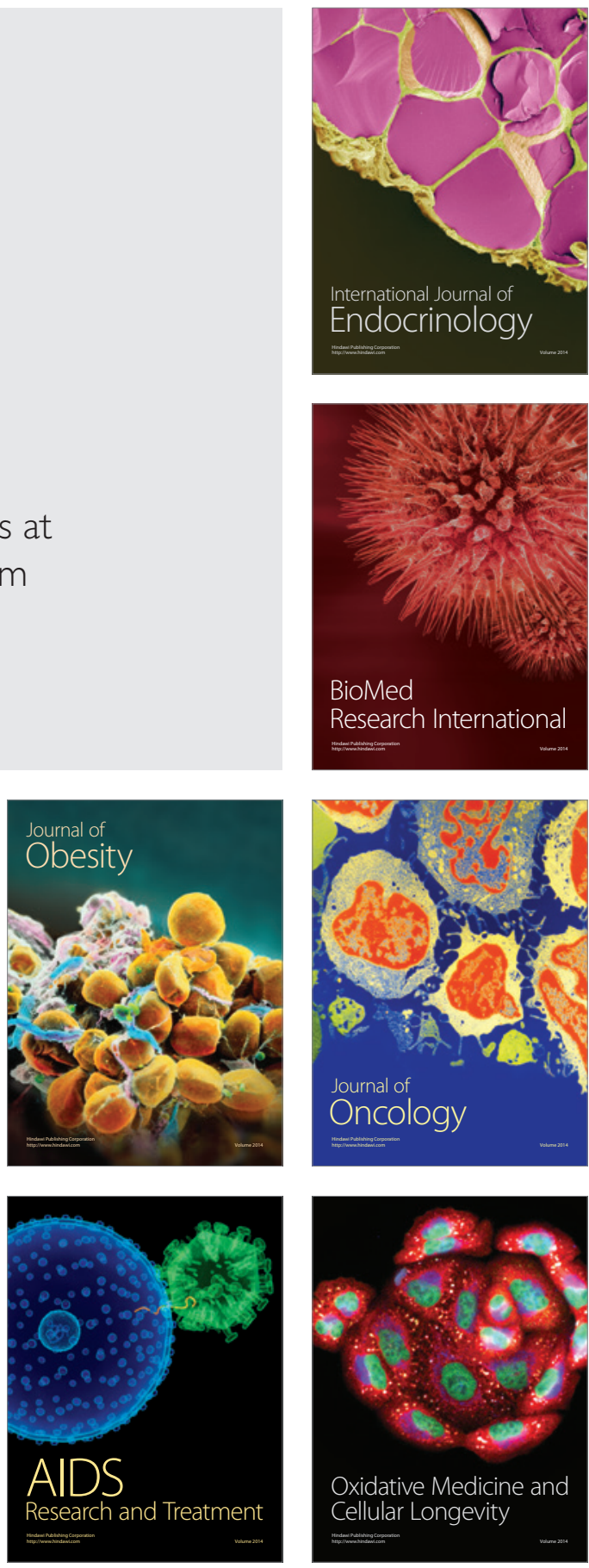